\title{
Literature systematic review on the ophthalmological side effects of interferons
}

\author{
Revisão sistemática da literatura sobre os efeitos adversos oftalmológicos dos interferons
}

\author{
Yara Dadalti Fragoso ${ }^{1}$, Marina Sanchez Sahm Paggiaro², Roberta Mastromauro², Gabriela da Silva Jacondino², Heather Marion Wilson ${ }^{3}$
}

\begin{abstract}
Interferons alpha and beta have been used worldwide for a few decades, altering the natural history of several severe diseases including hepatitis C, cancer and immunemediated conditions such as multiple sclerosis. The adverse events profile of interferons is well established, but only isolated reports of ophthalmological complications of interferon therapy have been published. The objective of this study was to carry out a literature systematic review on the subject, bringing to light the need for careful ophthalmological monitoring of patients undergoing interferon treatment. Nearly 500 cases of ophthalmological complications related to interferon have been reported. The most frequent findings were soft exudates, hemorrhages and retina ischemia.
\end{abstract}

Keywords: Eye; Retina; Interferonalpha/adverse effects; Interferon beta/adverse effects

\section{RESUMO}

Os interferons alfa e beta têm sido usado em todo o mundo por algumas décadas, mudando a história natural de diversas doenças graves, como hepatite C, câncer e condições imunomediadas como a esclerose múltipla. O perfil de eventos adversos dos interferons está bem definido, porém apenas relatos isolados das complicações oftalmológicas do tratamento com interferon foram publicados. O objetivo do presente trabalho foi a realização de uma revisão sistemática da literatura sobre o tema, trazendo à luz a necessidade de cuidadosa monitorização oftalmológica dos pacientes em tratamento com interferon. Quase 500 casos de complicações oftalmológicas relacionadas ao uso de interferon foram relatados. Os achados mais frequentes foram exsudatos, hemorragias e isquemia de retina.

Descritores:Olho; Retina; Interferon alfa/efeitos adversos; Interferon beta/efeitos adversos

\section{BACKGROUND}

Interferons are natural glycoproteins that have antiviral, antiproliferative and immune regulatory functions. There are several classes including interferon alpha, beta and gamma. Interferons alpha and beta are used worldwide in the treatment of several diseases including hepatitis C, cancer and immune-mediated conditions such as multiple sclerosis. Due to the long-term use of interferons for most patients, the safety profile of these compounds is well known. Cutaneous (1), hematological ${ }^{(2)}$, psychiatric ${ }^{(3,4)}$, endocrine ${ }^{(5)}$ and hepatic ${ }^{(6)}$ side effects of interferons have been reported. However, some side effects are specifically related to the eye, and a variety of ophthalmological diseases may arise from the use of interferons. Although recognised as relatively rare, ophthalmological complications due to interferons should be considered even if the patient is visually asymptomatic.

The literature on the subject is restricted to case reports or a small series of cases. In order to better understand the most frequent ophthalmological side effects of interferons and the outcome of these conditions, a literature systematic review was carried out.

\section{METHODS}

The present study was registered at the Investigational Review Board/Ethics Committee of Universidade Metropolitana de Santos, which waived the requirement for consent from participants, considering only previously published data were used. The PRISMA protocol ${ }^{7}$ was employed in order to guarantee the quality of the search and reporting.

Using the PICO framework, the authors independently searched for the terms "interferon" OR "interferon alpha" OR "interferon beta" AND "ophthalmology" OR "eye" AND "side effects" OR "adverse events" OR "adverse effects" in the following databases: Medline, Pubmed, Scopus, Index Medicus, Biomed Central, Ebsco Fulltext, LILACS, Scielo and the Cochrane Database of Systematic Reviews, up to December 2010. Abstracts of articles in any language containing these words in English (in the title, key words or abstract) were independently reviewed by the authors. Any differences in views were discussed and settled in a meeting between the authors.

Only published case reports (or case series) regarding human beings were included in the present review. Editorials, abstracts from scientific meetings, animal studies, expert opinions and duplicate reports were discarded.

Every effort was made to obtain the full text of all relevant papers, including contact with authors, editors of journals, and interlibrary loan. These articles were individually read by all of the authors, who summarized the results in an Excel ${ }^{\mathrm{TM}}$ file.

The qualitative characteristics of the present study did not foresee publication biases or treatment effects. Likewise, the exclusive data from case reports in the present study did not provide any (SP), Brazil.

Students, Medical Faculty, Universidade Metropolitana de Santos - UNIMES - Santos (SP), Brazil.

${ }^{3}$ Dentistry, University of Aberdeen, Institute of Medical Sciences, Foresterhill, Aberdeen (UK).

Funding: No specific financial support was available for this study.

Disclosure of potential conflicts of interest: Y.D.Fragoso, Consultant (Bayer-Schering, BiogenIdec, Boehringer-Ingelheim, Merck-Serono, Novartis, Roche, Sanofi-Aventis and TEVA), Recipient (Bayer-Schering, Biogen-Idec, Boehringer-Ingelheim, Merck-Serono, Novartis, Roche, SanofiAventis and TEVA), M.S.S.Paggiaro, None; R.Mastromauro, None; G.S.Jacondino, None; H.M.Wilson Financial Support (Research work from N.H.S Endowment funding, Medical Research Council and Cunningham Trust).

Correspondence address: Yara Dadalti Fragoso. Department of Neurology, Medical School, UNIMES Rua da Constituição 374, Santos (SP) - 11015-470 - Brazil - E-mail: yara@bsnet.com.br 
evidence for meta-analysis or statistical evaluation. The results were collected mainly for presentation of a summary table with the most frequently reported findings.

\section{RESULTS}

A search of published literature containing the terms outlined in "Methods" resulted in retrieval of 551 articles.

From these initial 551 papers, 457 were discarded due to a failure to meet the established inclusion criteria. Four papers could not be retrieved despite all efforts from the authors of the present study ${ }^{(9-12)}$. These journals had ceased publication or changed name and/or publisher, while attempts to contact the authors directly were not successful. From the abstract contents, it appeared that only two of these papers reported on $\operatorname{cases}^{(9-10)}$, while two others reviewed the subject without adding further cases $^{(11,12)}$.

The present study analyzed data from 88 papers on the subject, describing ophthalmological complications of interferon alpha and beta, published between 1993 and 2010(13-101).

The main findings from all 88 papers are summarized in table 1.

\section{INTERFERON ALPHA}

There were 471 reported cases of ophthalmological complications related to the use of interferon alpha ${ }^{(13-91)}$. Some series also included control subjects $(n=829)$ for normalization of the period of use and the dose of interferon al pha for similar populations. Only one paper presented three cases of children with ophthalmological complications due to interferon alpha treatment ${ }^{(85)}$, all other papers reported on adults.

From the 471 reported cases, $66.7 \%$ were in males and $33.3 \%$ were in females (although not all papers specified the patient gender). The average age was $46.3 \pm 10.0$ years ( 9 to 71 years). Twenty patients had been prescribed interferon alpha due to malignancies, while all the others $(n=449)$ were undergoing treatment for hepatitis $B$ and/or hepatitis $C$.
Soft retinal exudates were the main finding in $67.0 \%$ of these patients, followed by retinal hemorrhage and/or severe ischemia in $56.0 \%$ of them. The common denominator in all cases was decreased visual acuity as the patient's main complaint, although there were reports of virtually asymptomatic patients.

Associated retinal microaneurisms, diplopia, visual field defects, papillary edema, uveitis, thinning of nerve fiber layer, ocular myasthenia and/or occulomotor nerve paralysis, panophthalmitis, periphlebitis and unspecific retinal alterations were also reported in more than half of all cases.

A few cases of Vogt-Koyanagi-Harada disease have been described in association with hepatitis $C$ and interferon alpha plus ribavirin. Only cases with very clear relation between the drug and the side effect were included in the review.

The average time for the patient to develop visual symptoms was $21.9 \pm 18.1$ weeks from onset of interferon-alpha use. Only two case reports presented findings of patients with ophthalmological complications after one year of treatment.

\section{INTERFERON BETA}

There were 14 reported cases in ten papers relating ophthalmic complications due to the interferon beta use ${ }^{(92-101)}$. These patients consisted of three men and eleven women, with an average age of $37.0 \pm 13.1$ years (20 to 58 years). Eleven of these patients were prescribed interferon beta due to multiple sclerosis, one patient used interferon beta due to hepatitis $C$, and there was no clear diagnosis for the two remaining patients.

The average time for presenting decreased visual acuity and/or blurred vision was 21 weeks. However, two cases were not included in this calculation, since symptoms and retinopathy developed after several years of interferon beta treatment. These cases were in complete contrast to all the other cases of retinopathy due to interferon treatment.

All patients using interferon beta who have been reported as having ophthalmological complications of the treatment $(n=14)$ presented soft retinal exudates. In addition, two patients also pre-

Table 1. Summarized data on the main findings reported in the literature, regarding the association of interferon treatment and ophthalmological complications

\begin{tabular}{|c|c|c|c|c|}
\hline & Soft exudates & Hemorrhage & Ischemia & Others \\
\hline References & $\begin{array}{c}15,17,19,20,23,25,26, \\
27,28,29,30,31,33,34, \\
36,37,38,39,41,42,44, \\
46,47,49,50,52,53,56, \\
58,63,64,65,66,67,68, \\
70,71,73,74,76,78,79, \\
83,87,89,91,92,93, \\
94,95,96,97,98,99, \\
100,101,102,103 .\end{array}$ & $\begin{array}{l}15,17,18,25,27 \\
28,30,31,32,36 \\
37,38,39,41,42 \\
44,45,46,47,48 \\
49,52,56,58,59 \\
64,65,66,67,68 \\
69,70,74,77,78 \\
79,83,87,89,91 \\
92,93,94,98,103 .\end{array}$ & $\begin{array}{c}17,22,23,24,29, \\
31,32,35,38,43 \\
44,45,47,53,54 \\
56,59,61,63,65 \\
66,69,71,72,74, \\
76,78,79,80,84 \\
86,88,89,90,91 \\
92,93,96,102,103 .\end{array}$ & $\begin{array}{l}\text { Microaneurisms } 17,94 \\
\text { Periphlebitis } 19 \\
\text { Neovascular glaucoma } 20 \\
\text { Panophthalmitis } 22 \\
\text { Optic disc edema 23, 24, 41, 42, } \\
43,44,50,51,56,61,77,84,86 \\
\text { Thinning of fiber layer } 25 \\
\text { Conjunctival hemorrhage } 28 \\
\text { Visual field defects } 34 \\
\text { Thrombosis } 35,72 \\
\text { Photosensitivity } 40 \\
\text { Nerve paralysis } 43 \\
\text { Macular edema } 45,40, \\
65,68,90,94,103 \\
\text { Toxic retinopathy } 49 \\
\text { Uveitis } 51,87 \\
\text { Bilateral papilledema } 55 \\
\text { Exophthamia } 56 \\
\text { Choroid neovascularization } 64 \\
\text { Hyperemia of optic disc } 70 \\
\text { Vogt-Koyanagi-Harada } 48,71,91,92 \\
\text { Retina hypertension } 74 \\
\text { Unspecified retinal/optical } \\
\text { alterations } 73,75,81,82 \\
\text { Ocular myasthenia } 85\end{array}$ \\
\hline
\end{tabular}


sented retinal bleeding, one patient presented retinal infarction and one patient presented several vascular micro-occlusions.

\section{DISCUSSION}

The present study showed that the main ophthalmological complication from interferon treatment is essentially a vascular retinopathy (exudates, ischemia, and hemorrhages). This condition is not difficult to diagnosis in daily practice and should be routinely investigated in patients undergoing interferon alpha or beta treatment. The present systematic review did not identify reports on other ophthalmological complications (affecting ocular surface, ocular adnexa, lens or other tissue), and all interferon-related adverse events seem to be related to the retina and the optic nerve.

It has been highlighted by some authors that particular risk factors may be involved in the development of ophthalmological complications during the use of interferon. Hayasaka et al. reviewed the subject in $1998^{(28)}$ and concluded that systemic hypertension and diabetes mellitus were clear risk factors for eye disease during therapy with interferons. Chisholm et al. ${ }^{(102)}$ have reviewed the subject of asymptomatic ophthalmological disease in patients using interferon alpha. Although this was not the subject of the present review (which concentrated in symptomatic patients), the subject deserves attention. It is also important to consider that the association of interferons to other drugs, such as ribavirin, may favor the development of ophthalmological complications. Although most papers reviewed in the present work consider this possibility, it seems that only high blood pressure and diabetes are categorically considered severe risk factors of eye disease during the use of interferons.

Over the last two decades, treatment with interferons has became a common worldwide option for a variety of diseases. Most often, this treatment is used for long periods of time and monitoring of side effects is recommended. Cutaneous, hematological, psychiatric, endocrine and hepatic monitoring is well established by guidelines and clearly explained in leaflets accompanying the medication. On the other hand, ophthalmological side effects of interferons are not well known and there are no guidelines or recommendations for monitoring patients through regular ophthalmological consultations. Popular drug information websites both in English (www.medicinenet.com) and in Portuguese (www.bulas.med.br) do not have specific recommendations for ophthalmological assessments of patients using interferons. The website www.drugs.com recommends consultations in cases of blurred or double vision, but does not suggest regular consultations to detect possible alterations prior to symptoms.

The mechanism of damage to the eye caused by interferon is not completely understood. It is possible that the frequent exposure to interferon induces the production of autoantibodies leading to the deposition of immune complexes in the retina ${ }^{(31)}$. It is also plausible that the deposition of inflammatory cytokines in the arterial walls of the retina might be related to the development of ophthalmological adverse events ${ }^{(103)}$.

When a patient presents ophthalmological complications of the interferon treatment, the recommendation is to stop the therapy with interferon. Although many cases reported in the literature showed good outcomes when the interferon treatment was withdrawn, this was not observed in all patients. Especially for cases with vascular damage, the general outcome was incomplete recovery.

There are very few papers reporting on the prevalence of visual adverse events in a population of patients using interferons. One of these papers ${ }^{(43)}$ reports that, of all the interferon-related adverse events, $8.4 \%$ affected the eye. In contrast, Cuthbertson et al. ${ }^{(104)}$ analyzing their series of cases did not see any reason to recommend routine ophthalmological evaluation of patients using interferons.
The real extent of ophthalmological adverse events caused by interferons may be unknown, since ophthalmological investigation of these patients appears to be performed only when the patients complained of visual symptoms. In addition to the problem, the underlying diseases themselves may also cause visual symptoms. For example, blurred vision could be due to optical neuritis and diplopia may be related to brainstem lesions in multiple sclero$\operatorname{sis}^{(105,106)}$. Uveitis and retinal phlebitis have been reported as retinal manifestations of multiple sclerosis(107), and may add to the difficult differential diagnosis of visual disturbances in a patient with multiple sclerosis who takes interferon. Thus, the physician may consider that the underlying disease is worsening when, in fact, the symptoms could be an adverse effect of treatment. At least for patients at higher risk of developing other concomitant diseases or therapy complications, the association of interferon beta and antiviral therapy should be carefully monitored(108).

\section{CONCLUSION}

Although not particularly frequent, ophthalmological adverse effects related to the use of interferons have been reported in nearly five hundred individuals over less than three decades. These are patients who already suffer from chronic and debilitating conditions, and poor outcomes of visual affections may play a substantial role in worsening their quality of life. Retinal exudates, ischemia and hemorrhage should be actively investigated in patients undergoing treatment with interferons as part of the extensive monitoring of side effects of these compounds. Therefore, for the first six months of interferon treatment, when most complications have been described, routine ophthalmological assessments could improve the overall quality of care for these patients. If complications are present in a patient taking interferons, the general recommendation is to stop the treatment with this drug.

\section{REFERENCES}

1. Orasan O, Cozma A, Rednic N, Sâmpelean D, Pârvu A, Petrov L. Anemia-a complication of antiviral treatment in chronic viral hepatitis C. Rom J Intern Med. 2009;47(3):217-25.

2. Mistry N, Shapero J, Crawford RI. A review of adverse cutaneous drug reactions resulting from the use of interferon and ribavirin. Can J Gastroenterol. 2009;23(10):677-83. Erratum in Can J Gastroenterol. 2009;23(11):784.

3. Sockalingam S, Abbey SE. Managing depression during hepatitis C treatment. Can J Psychiatry. 2009;54(9):614-25

4. Fragoso YD, Frota ER, Lopes JS, Noal JS, Giacomo MC, Gomes S, et al. Severe depression, suicide attempts, and ideation during the use of interferon beta by patients with multiple sclerosis. Clin Neuropharmacol. 2010;33(6):312-6.

5. Nonchev BI. Cases of interferon-alpha and interferon-beta-induced thyroiditis. Folia Med (Plovdiv). 2010;52(3):5-12.

6. Tremlett $\mathrm{H}$, Oger J. Hepatic injury, liver monitoring and the beta-interferons for multiple sclerosis. J Neurol. 2004;251(11):1297-303. Review.

7. Moher D, Liberati A, Tetzlaff J, Altman DG; PRISMA Group. Preferred reporting items for systematic reviews and meta-analysis: the PRISMA statement. J Clin Epidemiol. 2009; 62(10):1006-12.

8. Schardt C, Adams MB, Owens T, Keitz S, Fontelo P. Utilization of the PICO framework to improve searching PubMed for clinical questions. BMC Med Inform Decis Mak. 2007;7:16

9. Sobolewski P, Lapi ski T. [A case report of interferon-associated retinopathy]. Klin Oczna 1999;101(3):213-6. Polish.

10. Kiratli $\mathrm{H}$, Irkeç M. Presumed interferon-associated bilateral macular arterial branch obstruction. Eye (Lond). 2000;14(Pt 6):920-2.

11. Interferon alfa, peginterferon alfa and retinopathy. Prescrire Int. 2006;15(82):61-2.

12. Kadayifcilar S, Boyacioglu S, Kart H, Gursoy M, Aydin P. Ocular complications with highdose interferon alpha in chronic active hepatitis. Eye (Lond). 1999;13(Pt 2):241-6.

13. Ikebe T, Nakatsuka K, Goto M. A case of retinopathy induced by intravenous administration of interferon. Folia Ophthalmol Jpn. 1990;41:2291-6.

14. Bauherz G, Soeur M, Lustman F. Oculomotor nerve paralysis induced by alfa Il-interferon. Acta Neurol Belg. 1990;90(2):111-4.

15. Guyer DR, Tiedeman J, Yannuzzi LA, Slakter JS, Parke D, Kelley J, et al. Interferon-associated retinopathy. Arch Ophthalmol. 1993;111(3):350-6.

16. Kado M, Yoshida A, Sakagami S. Retinopathy in patients with type C hepatitis during interferon therapy. J Jpn Ophthalmol Assoc. 1993;64:961-5.

17. Miyamoto K, Suda T, Motokura M, et al. Retinopathy in interferon-alfa treatment. J Eye. 1993;10:497-500. 
18. Kubo E, Tsuzuki S, Kobayashi T, et al. Six cases of interferon-associated retinopathy. Folia Ophthalmol Jpn. 1994;45:886-90.

19. Ayaki M. Development of neovascular glaucoma in the course of interferon alfa therapy for hepatitis type C. Br J Ophthalmol. 1994;78(3):238.

20. Yoshitoshi T, Saegusa K, Watanabe A, et al. A case of panophthalmitis developed during interferon therapy. Jpn J Clin Ophthalmol. 1994;48:692-3.

21. Tadokoro Y, Ohtsuki H, Okano M, Furuse T. A case of disc edema during systemic interferon therapy. Folia Ophthalmol Jpn. 1995;46:653-6.

22. Purvin VA. Anterior ischemic optic neuropathy secondary to interferon alfa. Arch Ophthamol. 1995;113(8):1041-4.

23. Hayasaka S. Interferon-associated retinopathy. J Jpn Ophthalmologists Assoc. 1997;68: 231-3.

24. Kawano T, Shigehira M, Uto H, Nakama T, Kato J, Hayashi K, et al. Retinal complications during interferon therapy for chronic hepatites C. Am J Gastroenterol. 1996;91(2):309-13.

25. Chen LL, Onishi A, Kawano C, Yagi I, Shinozaki K.. Interferon-associated retinopathy in patients receiving systemic interferon therapy. Folia Ophthalmol Jpn. 1996;47:1263-8.

26. Louvet B, Sales MJ, Souid M, Barbanel C. Rétinopathie à l'interféron. A propos d'un cas. J Fr Ophtalmol. 1997:20(8):624-7.

27. Chambers RB, Downie A, Foote B, Davidorf FH. Interferon alfa-associated retinopathy. J Am Osteopath Assoc. 1997;97(1):43-5.

28. Hayasaka S, Nagaki Y, Matsumoto M, Sato S. Interferon associated retinopathy. Br J Ophthalmol. 1998;82(3):323-5. Review.

29. Sugano S, Suzuki T, Watanabe M, Ohe K, Ishii K, Okajima T. Retinal complications and plasma C5a levels during interferon alpha therapy for chronic hepatitis C. Am J Gastroenterol. 1998;93(12):2441-4.

30. Manesis EK, Moschos M, Brouzas D, Kotsiras J, Petrou C, Theodosiadis G, Hadziyannis S. Neurovisual impairment: a frequent complication of alpha-interferon treatment in chronic viral hepatitis. Hepatology. 1998;27(5):1421-7.

31. Lohmann CP, Kroher G, Bogenrieder T, Spiegel D, Preuner J. Severe loss of vision during adjuvant interferon alfa-2b treatment for malignant melanoma. Lancet. 1999;353(9161):1326.

32. Neubauer AS, Hoops JP. [Bilateral retinal microangiopathy in interferon therapy of malignant melanoma of the skin]. Klin Monbl Augenheilkd. 2000;217(5):308-11. German

33. Nadir A, Amin A, Chalisa N, van Thiel DH. Retinal vein thrombosis associated with chronic hepatitis C: a case series and review of the literature. J Viral Hepat. 2000;7(6):466-70.

34. Esmaeli B, Koller C, Papadopoulos N, Romaguera J. Interferon-induced retinopathy in asymptomatic cancer patients. Ophthalmology. 2001;108(5):858-60.

35. Jain K, Lam WC, Waheeb S, Thai Q, Heathcote J. Retinopathy in chronic hepatitis C patients during interferon treatment with ribavirin. Br J Ophthalmol. 2001;85(10):1171-3.

36. Saito H, Ebinuma H, Nagata H, Inagaki Y, Saito Y, Wakabayashi K, et al. Interferon-associated retinopathy in a uniform regimen of natural interferon-alpha therapy for chronic hepatitis C. Liver. 2001;21(3):192-7.

37. Hejny C, Sternberg P, Lawson DH, Greiner K, Aaberg TM Jr. Retinopathy associated with high-dose interferon alpha-2b therapy. Am J Ophthalmol. 2001;131(6):782-7.

38. Kondo M, Murakawa Y, Sumita Y, Masuda H, Kobayashi S. Lupus retinopathy associated with a high IFN-alpha level in the cerebrospinal fluid. Intern Med. 2002;41(9):754-6.

39. Vardizer $Y$, Linhart $Y$, Loewenstein A, Garzozi H, Mazawi N, Kesler A. Interferon-alphaassociated bilateral simultaneous ischemic optic neuropathy. J Neuroophthalmol. 2003; 23(4):256-9.

40. Schulman JA, Liang C, Kooragayala LM, King J. Posterior segment complications in patients with hepatitis $C$ treated with interferon and ribavirin. Ophthalmology. 2003, 110(2):437-42.

41. Kargi $\mathrm{SH}, \mathrm{Oz} \mathrm{O}$, Ustündag Y, Firat E. Epiretinal membrane development during interferon treatment. Can J Ophthalmol. 2003;38(7):610-2.

42. Rubio JE Jr, Charles S. Interferon-associated combined branch retinal artery and central retinal obstruction. Retina. 2003;23(4):546-8.

43. Ockenfels M, Lisch W. [Ocular complications of adjuvant interferon therapy for malignant melanoma: a review]. Hautarzt. 2003;54(2):144-7. German.

44. Tsolakos A, Zalatimo N. Hepatitis C: a review of diagnosis, management, and ocular complications for treatment. Optometry. 2003;74(8):517-23.

45. Tu KL, Bowyer J, Schofield K, Harding S. Severe interferon associated retinopathy. $\mathrm{Br}$ Ophthalmol. 2003;87(2):247-8

46. Sylvestre DL, Disston AR, Bui DP. Vogt-Koyanagi-Harada disease associated with interferon alpha-2b/ribavirin combination therapy. J Viral Hepat. 2003;10(6):467-70.

47. Crochet M, Ingster-Moati I, Even G, Dupuy P. Rétinopathie à l'interféron-alpha associé à la ribavirine: atteinte de l'électro-oculogramme. À propos d'un cas. J Fr Ophtalmol. 2004 27(3):257-62.

48. Foroozan R. Unilateral pallid optic disc swelling and anemia associated with interferon alpha treatment. J Neuroophthalmol. 2004;24(1):98-9. Comment on J Neuroophthalmol. 2003; 23(4):256-9.

49. Kasahara A, Hiraide A, Tomita N, Iwahashi H, Imagawa A, Ohguro N, et al. Vogt-Koyanagi-Harada disease occurring during interferon alpha therapy for chronic hepatitis C. J Gastroenterol. 2004;39(11):1 106-9. Review.

50. Jung LS, Ciola FB, Conceição RDO, Silva AEB, Moraes NSB. Ocular changes due to systemic alpha-interferon therapy for hepatitis C. Arq Bras Oftalmol. 2004;67(6):917-20.

51. Sandner D, Pillunat LE. [Reversible Perimacular Retinopathy by Long-Time Interferon alpha Therapy]. Klin Monbl Augenhailkd. 2004;221(1):63-6. German.

52. Wilson RA. Visual side effects of pegylated interferon during therapy for chronic hepatitis $C$ infection. J Clin Gastroenterol. 2004;38(8):717-22. Review.
53. Kirchhoff A, Kirchhoff U, Lafrenz M, Guthoff R. [Bilateral AlON after the combined therapy of hepatitis C with PEG-interferon alpha2B and ribavirin]. Klin Monbl Augenheilkd. 2004;221(9):791-3. German

54. Nakamura A, Tojo K, Takasu K, Kaneko K, Komastu H, Ikeda S. Unilateral oculomotor nerve palsy induced by combination therapy of interferon-alpha2b and ribavirin. Intern Med. 2005;44(6):682-3.

55. Nakamura T, Takahashi H, Koike N, Mitsutaka M, Soda M, Kimu M. [Retinopathy during interferon treatment in combination with ribavirin for chronic hepatitis C]. Nihon Ganka Gakkai Zasshi. 2005;109(11):748-52. Japanese.

56. Nicolò M, Artioli S, La Mattina GC, Ghiglione D, Calabria G. Branch retinal artery occlusion combined with branch retinal vein occlusion in a patient with hepatitis $C$ treated with interferon and ribavirin. Eur J Ophthalmol. 2005;15(6):811-4

57. Shimura M, Saito T, Yasuda K, Tamai M. Clinical course of macular edema in two cases of interferon-associated retinopathy observed by optical coherence tomography. Jpn J Ophthalmol. 2005:49(3):231-4.

58. Miserachs-García S, Mesa-Toledo E, Arruga-Ginebreda J, Castillo-Campillo L. [Ischemic neuroretinopathyassociated with use ofinterferon].Arch SocEsp Oftalmol.2005;80(9):533-5. Spanish.

59. Schmidt S, Pleyer U. Interferon-a-assoziierte Retinopathie bei Patienten mit chronischer Hepatitis C. Klin Monatsbl Augenheilkd. 2005;222(11):915-8.

60. Yaghi C, Baz P, Koussa S, Daniel F, Haddad F, Sayegh R. [lschemic anterior optic neuropathy complicating interferon alpha-2a and ribavirin treatment for acute hepatitis C]. Gastroenterol Clin Biol. 2005;29(5):616-7. French.

61. d'Alteroche L, Majzoub S, Lecuyer AL, Delplace MP, Bacq Y. Ophthalmologic side effects during alpha-interferon therapy for viral hepatitis. J Hepatol. 2006;44(1):56-61. Comment in J Hepatol. 2006:45(1):160-1; author reply 161-2.

62. Bazarah SM, Ritenour R, Patel ST, Hirsch G, Peltekian KM, Cruess AF. Choroidal neovascularization with interferon associated retinopathy: case report and review of literature. Ann Hepatol. 2006;5(3):172-6.

63. Stoffelns BM. [Interferon causes ischemic ocular diseases-case studies and review of the literature]. Klin Monbl Augenheilkd. 2006;223(5):367-71. German.

64. Gonçalves LL, Farias AQ, Gonçalves PL, D'Amico EA, Carrilho FJ. Branch retinal vein thrombosis and visual loss probably associated with pegylated interferon therapy of chronic hepatitis C. World J Gastroenrol. 2006:12(28):4602-3.

65. Okuse C, Yotsuyanagi H, Nagase Y, Kobayashi Y, Yasuda K, Koike K, et al. Risk factors for retinopathy associated with interferon alpha- $2 \mathrm{~b}$ and ribavirin combination therapy in patients with chronic hepatitis C. World J Gastroenterol. 2006;12(23):3756-9.

66. Andrade RJ, González FJ, Vázquez L, Cilvetti A, Camargo R, García-Cortés M, et al. Vascular ophthalmological side effects associated with antiviral therapy for chronic hepatitis $C$ are related to vascular endothelial growth factor levels. Antivir Ther. 2006;11(4):491-8.

67. Helal Júnior J, Zacharias LC, Alencar LM. Central vein occlusion in a patient using interferon and ribavirin: case report. Arq Bras Oftalmol. 2006;69(4):601-4.

68. Avila MP, Freitas AM, Isaac DLC, Bastos ALM, Pena RV. Retinopatia em paciente portador de hepatite C tratado com interferon peguilado e ribavirina: relato de caso. Arq Bras Oftalmol. 2006;69(2):255-9.

69. Papastathopoulos K, Bouzas E, Naoum G, Vergados I, Tsiodras S. Vogt-Koyanagi-Harada disease associated with interferon-A and ribavirin therapy for chronic hepatitis $C$ infection. $J$ Infect. 2006;52(2):e59-61.

70. Zandieh I, Adenwalla M, Cheong-Lee C, Ma PE, Yoshida EM. Retinal vein thrombosis associated with pegylated-interferon and ribavirin combination therapy for chronic hepatitis C. World J Gastroenterol. 2006;12(30):4908-10.

71. Sauer A; Lenoble P, Bader P, Speeg-Schatz C, Bourcier T, Nasica X. Complications ophtalmologiques du traitement de I'hepatite C. J Fr Ophthalmol 2007;30(7): e20.

72. Sene D, Touitou V, Bodaghi B, Saadoun D, Perlemuter G, Cassoux N, et al. Intraocular complications of IFN-alpha and ribavirin therapy in patients with chronic viral hepatitis $C$. World J Gastroenterol. 2007;13(22):3137-40.

73. Nagaoka T, Sato E, Takahashi A, Yokohama S, Yoshida A. Retinal circulatory changes associated with interferon-induced retinopathy in patients with hepatitis C. Invest Ophthalmol Vis Sci. 2007:48(1):368-75.

74. Mantel I, Konstantinidis L, Zografos L. Interferon-associated retinopathy-a case report. Klin Monatsbl Augenheilkd. 2007;224(4):350-2.

75. Khan H, Hamid K, Feroze AH. Interferon associated retinopathy. J Pak Med Assoc. 2008; 58(1):48-9.

76. Murata M, Tamura Y, Ohsawa M, Hirano T, Matsuo T, Murata T. Central retinal vein occlusion in hypertensive patients with chronic hepatitis $\mathrm{C}$ treated with interferon alpha and ribavirin. Jpn J Ophthalmol. 2008;52(6):511-3.

77. Kim ET, Kim LH, Lee Jl, Chin HS. Retinopathy in hepatitis C patients due to combination therapy with pegylated interferon and ribavirin. Jpn J Ophthalmol. 2009;53(6):598-602.

78. Chrissafidou A, Musch E. [Peripheral polyneuropathy and bilateral optic neuropathy during treatment of chronic hepatitis C]. Dtsch Med Wochenschr. 2009:134(18):927-30. German

79. Viennet A, Glatre F, Bacin F. [Interferon-related retinopathy in a men with chronic hepatitis C]. J Fr Ophtalmol. 2009;32(7):505-10. French.

80. Panetta JD, Gilani N. Interferon-induced retinopathy and its risk in patients with diabetes and hypertension undergoing treatment for chronic hepatitis C virus infection. Aliment Pharmacol Ther. 2009;30(6):597-602

81. Mehta N, Murthy UK, Kaul V Alpert S, Abruzzese G, Teitelbaum C. Outcome of retinopathy in chronic hepatitis C patients treated with peginterferon and ribavirin. Dig Dis Sci. 2010; 55(2):452-7. 
82. Wei $Y H$, Wang $I H$, Woung LC, Jou JR. Anterior ischemic optic neuropathy associated with pegylated interferon therapy for chronic hepatitis C. Ocul Immunol Inflamm. 2009;17(3):191-4.

83. Kang HM, Park MJ, Hwang JM, Kim JW, Jeong SH. Development of ocular myasthenia during pegylated interferon and ribavirin treatment for chronic hepatitis C. Korean J Hepatol. 2009; 15(2):209-15

84. Kabbaj N, Sentissi S, Mohammadi M, Benaïssa A, Amrani N. Anterior ischemic optic neuropathy complicating interferon alpha and ribavirin therapy in patients with chronic hepatitis $C$. Gastroenterol Clin Biol. 2009;33(2):115-7.

85. Narkewicz MR, Rosenthal P, Schwarz KB, Drack A, Margolis T, Repka MX; PEDS-C Study Group. Ophthalmologic complications in children with chronic hepatitis $C$ treated with pegylated interferon. J Pediatr Gastroenterol Nutr. 2010;51(2):183-6.

86. Berg KT, Nelson B, Harrison AR, McLoon LK, Lee MS. Pegylated interferon alpha-associated optic neuropathy. J Neuroophthalmol. 2010:30(2):117-22.

87. Adams S, Ostermeier M. Retinopathy associated with pegylated interferon and ribavirin treatment for chronic hepatitis C. Optometry. 2010;81(11):580-6.

88. Sheth HG, Michaelides M, Siriwardena D. Cystoid macular edema and visual loss as sequelae to interferon alpha treatment of systemic hepatitis C. Indian J Ophthalmol. 2010;58(2):147-8.

89. Al-Muammar AM, Al-Mudhaiyan TM, Al Otaibi M, Abdo A, Abu El-Asrar AM. Vogt-KoyanagiHarada disease occurring during interferon-alpha and ribavirin therapy for chronic hepatitis C virus infection. Int Ophthalmol. 2010;30(5):611-3.

90. Chebil A, Kort F, Bouraoui R, Youssef NB, El Matri L. IVogt-Koyanagi-Harada disease associated with interferon-alpha and ribavirin therapy for chronic hepatitis $C$ infection. J Fr Ophtalmol. 2010;33(3):185-8. French.

91. Rossi C, Scotton PG, Farina F, Vaglia A. Retinopathy in chronic hepatitis C patients during interferon treatment: a case report. Infez Med. 2010;18(4):267-9

92. Tokai R, Ikeda T, Miyaura T, Sato K. Interferon-associated retinopathy and cystoid macular edema. Arch Ophthalmol. 2001;119(7):1077-9.

93. Sommer S, Sablon JC, Zaoui M, Rozot P, Hosni A. Rétinopathie à l'interféron bêta au cours d'une sclérose en plaques. J Fr Ophtalmol. 2001;24(5):509-12

94. Mallada-Frechín J, Abellán-Miralles I, Alfaro-Beltra ML, Medrano V, Muñoz-Gil MB, Fer-
nández-Izquierdo S, Piqueras-Rodríguez L. [Retinopathy secondary to treatment with interferon beta-1a in a patient with multiple sclerosis]. Rev Neurol. 2005;40(8):482-4. Spanish.

95. Longmuir R, Lee AG, Rouleau J. Cotton wool spots associated with interferon beta-1 alpha therapy. Semin Ophthalmol. 2007;22(1):49-53.

96. Saito H, Suzuki M, Asakawa T, Kato S. Retinopathy in a multiple sclerosis patient undergoing interferon-therapy. Mult Scler. 2007;13(7):939-40

97. Folden DV, Lee MS, Ryan EH Jr. Interferon beta-associated retinopathy in patients treated for multiple sclerosis. Neurology. 2008;70(13 Pt 2):1153-5.

98. Ohira M, Ito D, Shimizu T, Shibata M, Ohde H, Suzuki N. Retinopathy: an overlooked adverse effect of interferon-beta treatment of multiple sclerosis. Keio J Med. 2009;58(1):54-6.

99. Sallansonnet-Froment M, Roux X, de Greslan T, Bounolleau P, Taillia H, Ricard D, et al. [Interferon-beta retinopathy]. Rev Neurol (Paris). 2009;165(11):971-4. French.

100. Post JW, Colleaux K. Interferon beta retinopathy in a patient with multiple sclerosis. Can J Ophthalmol. 2009; $44(5): e 37$.

101. Martinez de Aragon JS, Pulido JS, Haupert CL, Blodi CF, Nielsen JS, Jampol LM. Interferon[beta]-associated retinopathy. Retin Cases Brief Rep. 2009;3(1):24-6.

102. Chisholm JA, Williams G, Spence E, Parks S, Keating D, Gavin M, Mills PR. Retinal toxicity during pegylated alpha-interferon therapy for chronic hepatitis $\mathrm{C}$ : a multifocal electroretinogram investigation. Aliment Pharmacol Ther. 2005;21(6):723-32.

103. Taylor JL, Grossberg SE. The effects of interferon-alpha on the production and action of other cytokines. Semin Oncol. 1998:25(1 Suppl 1):23-9.

104. Cuthbertson FM, Davies M, McKibbin M. Is screening for interferon retinopathy in hepatitis C justified? Br J Ophthalmol. 2004;88(12):1518-20.

105. Simao LM. Ophthalmologic manifestations commonly misdiagnosed as demyelinating events in multiple sclerosis patients. Curr Opin Ophthalmol. 2010;21(6):436-41.

106. Prasad S, Galetta SL. Eye movement abnormalities in multiple sclerosis. Neurol Clin. 2010; 28(3):641-55.

107. Kerrison JB, Flynn T, Green WR. Retinal pathologic changes in multiple sclerosis. Retina 1994;14(5):445-51.

108. Ferguson MC. Current therapies for chronic hepatitis C. Pharmacotherapy. 2011;31(1):92-111.

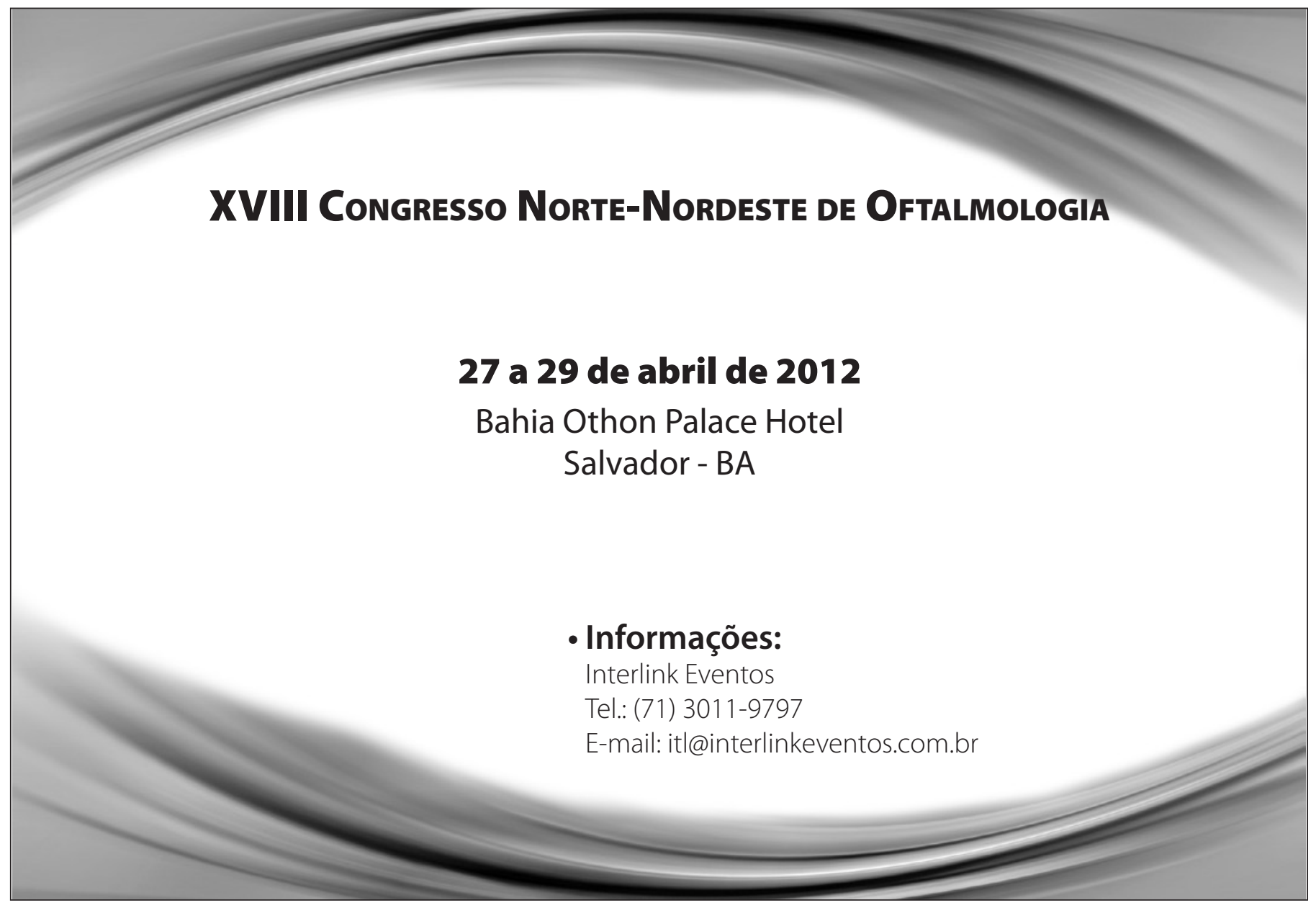

